\title{
PENGARUH AKTIVITAS, MINAT DAN OPINI TERHADAP KEPUTUSAN KONSUMEN MENGGUNAKAN JASA SALON CHIQUITA DI KOTA PALU
}

\author{
WIDYA LESTARI \\ SYAMSUL BACHRI \\ PONIRIN \\ Jurusan Manajemen, Fakultas Ekonomi, Universitas Tadulako \\ Email: widyalestari300@ rocketmail.com
}

\begin{abstract}
The purpose of the research is to find out the influence of activity, interest, and opinion on consumer decision in using Chiquita Salon in Palu City. There are 4 variables that used in this research; activity (X1), interest (X2), opinion (X3), and decision of the consumer (Y). Method of study is descriptive causal with a total sample of 60 respondents, who were selected by purposive sampling. Tool of analysis is multiple linear regressions with Software SPPS 17. The result finds that activity (X1), interest (X2), and opinion (X3) simultaneously influence the decision of the consumer in using Chiquita Salon in Palu City, with the level of significance of $0.000<\alpha 0.05$. Furthermore, activity (X1) with the t-sig. value of 0.042; interest (X2) has the t-sig. value of 0.022; opinion (X3) has the tsig. value of 0.001 . These values are $<0.05$, which means that each variable partially influences the decision of the consumer in using Chiquita Salon in Palu City.
\end{abstract}

Keywords: AIQ, consumers' decision, and Chiquita Salon

Abstrak

Tujuan dari penelitian ini adalah untuk mengetahui pengaruh aktivitas, minat, dan pendapat konsumen terhadap keputusan menggunakan Chiquita Salon di Kota Palu. Ada 4 variabel yang digunakan dalam penelitian ini; aktivitas (X1), minat (X2), pendapat (X3), dan keputusan konsumen (Y). Metode penelitian adalah deskriptif kausal dengan total sampel sebanyak 60 responden, yang dipilih secara purposive sampling. Alat analisis regresi linier berganda dengan Software SPPS 17. Hasilnya menemukan bahwa aktivitas (X1), minat (X2), dan pendapat (X3) berpengaruh secara simultan terhadap keputusan konsumen dalam menggunakan Chiquita Salon di Kota Palu, dengan tingkat signifikansi $0,000<\alpha \quad 0,05$. Selanjutnya, aktivitas (X1) dengan t-sig. nilai 0,042 ; minat (X2) memiliki t-sig. nilai 0,022 ; pendapat (X3) memiliki t-sig. nilai 0,001 . Nilai ini $<0,05$, yang berarti bahwa masing-masing variabel mempengaruhi secara parsial keputusan konsumen dalam menggunakan Chiquita Salon di Kota Palu.

Kata Kunci: AIQ, keputusan konsumen, dan Chiquita Salon

\section{PENDAhUluan}

\section{Latar Belakang Penelitian}

Seiring dengan perubahan gaya hidup khususnya di daerah Kota Palu yang mana masyarakatnya mempunyai segudang aktifitas kini sudah semakin memperhatikan penampilan mereka untuk memenuhi perkembangan zaman, yaitu dengan cara melakukan perawatan di salon kecantikan. Pendekatan gaya hidup menurut Plummer cenderung mengklasifikasikan konsumen berdasarkan variabel-variabel AIO yaitu: activity (aktifitas), interest (minat) dan opinion (pendapat) (Setiadi, 2013:80).

Perusahaan yang akan menjadi objek penelitian penulis dalam pembuatan tugas akhir ini adalah sebuah jasa pelayanan kecantikan yakni Salon Chiquita yang berlokasi di Jalan I Gusti Ngurah Rai Ruko Petak 70 E, Palu. Salon Chiquita ini merupakan salah satu salon kecantikan yang sudah berdiri sejak 6 tahun yang lalu di kota Palu. Salon Chiquita adalah tempat perawatan yang modern juga berfasilitas lengkap untuk perawatan kecantikan rambut, wajah dan relaksasi tubuh, dilengkapi dengan peralatan modern yang didukung oleh tenaga-tenaga profesional di bidangnya. Tersedia pula ruang khusus bagi yang mengutamakan privacy dan kenyamanan tersendiri. Salon Chiquita tidak hanya menerima potong rambut dan perawatan-perawatan rambut saja, namun juga menerima 
perawatan tubuh seperti facial, totok aura, SPA, bikini waxing, dan perawatan kuku. Pada mulanya Salon Chiquita hanya bermodalkan 3 meja dan 1 tempat untuk mencuci rambut, Salon Chiquita berhasil berkembang hingga saat ini, dan sekarang sudah mempunyai 1 cabang yaitu di Jalan Poebongo Ruko Catur No. 13.

Terlihat dari dimensi gaya hidup yaitu aktivitas, minat, dan opini (AIO), salon kecantikan bagi masyarakat tidak hanya sebatas tempat merawat rambut maupun kulit wajah, melainkan merupakan cerminan gaya hidup dan kepribadian masyarakat sehingga salon kecantikan bagi mereka digunakan sebagai perlambang status kepribadian bahkan bisa jadi sebagai sarana agar seseorang dapat diterima dalam kelompok tertentu, kelompok masyarakat secara potensial memanfaatkan salon kecantikan sebagai gaya hidupnya.

Selain dapat digunakan berinteraksi antar individu atau kelompok, media sosial instagram juga dapat digunakan oleh para pembisnis sebagai wadah untuk mengkomunikasikan produk maupun jasa yang ingin ditawarkan perusahaannya. Selain itu konsumen juga lebih dimudahkan untuk mencari produk atau jasa yang mereka inginkan.

Berdasarkan uraian di atas maka penulis ingin melakukan penelitian lebih rinci tentang adanya dugaan pengaruh aktivitas, minat, dan opini terhadap keputusan konsumen menggunakan jasa Salon Chiquita di Kota Palu.

\section{Permasalahan Penelitian}

Berdasarkan uraian latar belakang penelitian di atas, maka dikemukakan rumusan masalah dalam penelitian ini sebagai berikut:

1. Apakah aktivitas, minat, dan opini secara simultan (serempak) berpengaruh signifikan terhadap keputusan konsumen menggunakan jasa Salon Chiquita di Kota Palu?

2. Apakah aktivitas berpengaruh signifikan terhadap keputusan konsumen menggunakan jasa Salon Chiquita di Kota Palu?

3. Apakah minat berpengaruh signifikan terhadap keputusan konsumen menggunakan jasa Salon Chiquita di Kota Palu?

4. Apakah opini berpengaruh signifikan terhadap keputusan konsumen menggunakan jasa Salon Chiquita di Kota Palu?

\section{Tujuan Penelitian}

Berdasarkan permasalahan yang telah diajukan, maka dapat disusun tujuan dari penelitian yaitu sebagai berikut:

1. Untuk mengetahui dan menganalisis pengaruh simultan dari variabel aktivitas, minat, dan opini terhadap keputusan konsumen menggunakan jasa Salon Chiquita di Kota Palu.

2. Untuk mengetahui pengaruh aktivitas terhadap keputusan konsumen menggunakan jasa Salon Chiquita di Kota Palu.

3. Untuk mengetahui pengaruh minat terhadap keputusan konsumen menggunakan jasa Salon Chiquita di Kota Palu.

4. Untuk mengetahui pengaruh opini terhadap keputusan konsumen menggunakan jasa Salon Chiquita di Kota Palu.

\section{KAJIAN LITERATUR DAN PENGEMBANGAN HIPOTESIS \\ Pengertian Pemasaran}

Sunyoto (2014:5) mengemukakan bahwa pemasaran adalah satu proses sosial yang mana individu dan kelompok mendapatkan apa yang mereka butuhkan dan inginkan dengan menciptakan dan mempertukarkan produk dan nilai dengan individu dan kelompok lainnya.

\section{Gaya Hidup Dan Nilai}

Kotler dan Keller (2009:175), mengemukakan bahwa gaya hidup (lifestyle) pola hidup seseorang di dunia yang tercermin dalam kegiatan, minat, dan pendapat. Pola hidup seseorang seperti yang dinyatakan dalam kegiatan, minat dan pendapat. Dengan memahami perilaku pelanggan secara tepat, perusahaan sebagai penyedia sebuah produk harus dapat mengkomunikasikan nilai dari produknya melalui desain yang diciptakan. 
Keputusan konsumen juga dipengaruhi oleh nilai inti (core values), sistem kepercayaan yang mendasari sikap dan perilaku. Nilai inti lebih dalam daripada perilaku atau sika dan menentukan pilihan dan keinginan seseorang pada tingkat dasar dalam jangka panjang. Pemasar yang membidik konsumen berdasarkan nilai-nilai percaya bahwa bila produk sesuai dengan kepribadian dalam diri konsumen produk itu dapat mempengaruhi kepribadian luar dan perilaku pembelian konsumen (Kotler dan Keller, 2009:176).

\section{METODE PENELITIAN}

\section{Definisi Operasional Variabel}

Penelitian ini terdiri dari dua jenis variabel yaitu variabel bebas (independen/X) serta variabel terikat (dependen/Y). Penelitian ini bertujuan untuk mengetahui sejauh mana pengaruh dari variabel independen yaitu dimensi gaya hidup (aktivitas, minat, dan opini) (X) terhadap variabel dependen yaitu konsumen $(\mathrm{Y})$.

\section{Metode Pengumpulan Data}

Metode pengumpulan data yang digunakan dalam penelitian ini yaitu:

1. Observasi, yaitu metode pengumpulan data yang dilakukan dengan mengadakan pengamatan langsung pada objek penelitian untuk mengetahui sejauh mana pengaruh dimensi gaya hidup terhadap keputusan konsumen menggunakan jasa Salon Chiquita di Kota Palu.

2. Wawancara, yaitu metode pengumpulan data yang dilakukan dengan proses tanya jawab terhadap responden secara lisan (tidak terstruktur) baik terhadap konsumen yang dipilih sebagai responden maupun yang dinilai bisa memberikan informasi mengenai data yang dibutuhkan.

3. Kuesioner, yaitu metode pengumpulan data yang dilakukan dengan mengedarkan sejumlah pertanyaan melalui angket atau daftar pertanyaan yang terstruktur yang ditujukan kepada konsumen Salon Chiquita di Kota Palu yang dipilih sebagai responden penelitian.

\section{Metode Analisis}

Untuk menjawab permasalahan dan menguji hipotesis dalam penelitian ini analisis kualitatif dengan memaparkan hasil-hasil penelitian di lapangan secara deskriptif dan analisis kuantitatif dengan menggunakan angka-angka statistik melalui penggunaan alat analisis Regresi Linear Berganda (Multiple Linear Regression).

\section{HASIL DAN PEMBAHASAN \\ Profil Responden}

Profil responden dalam penelitian ini merupakan informasi yang disusun berdasarkan data yang diberikan oleh konsumen pada saat memberikan tanggapan terhadap pernyataan dalam kuesioner yang diajukan untuk mengetahui pengaruh bauran gaya hidup terhadap keputusan konsumen menggunakan jasa Salon Chiquita di Kota Palu. Informasi yang diperoleh berdasarkan profil responden akan memberikan gambaran tentang kecenderungan identitas konsumen yang menggunakan jasa Salon Chiquita pada saat penelitian dilakukan.

Selanjutnya akan diuraikan secara detail profil responden yang diklasifikasikan berdasarkan jenis kelamin, usia, pekerjaan, pendapatan, dan berapa lama menjadi pelanggan pada Salon Chiquita.

\section{Profil Responden Berdasarkan Jenis Kelamin}

Berdasarkan hasil penelitian ini, diketahui bahwa konsumen yang mendominasi berlangganan di Salon Chiquita adalah berjenis kelamin perempuan dengan jumlah sebanyak 71,7 \%. Sedangkan konsumen yang berjenis kelamin laki-laki berjumlah $28,3 \%$. Informasi ini memberikan makna bahwa wanita lebih cenderung menjadi pelanggan Salon Chiquita.

Berikut ini adalah gambar 1. yang menunjukan identitas responden berdasarkan jenis kelamin. 


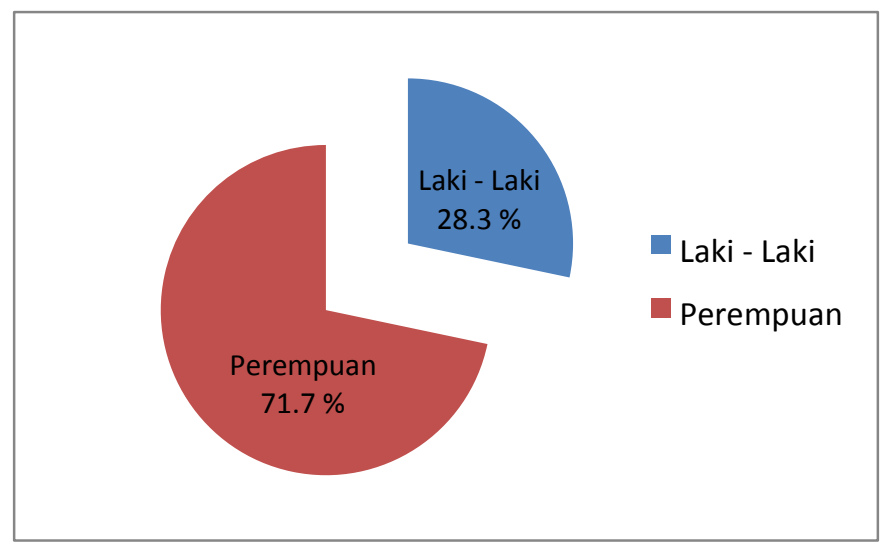

Gambar 1. Profil Responden Berdasarkan Jenis Kelamin

\section{Profil Responden Berdasarkan Usia}

Berdasarkan hasil penelitian, berikut ini adalah distribusi identitas responden berdasarkan usia.

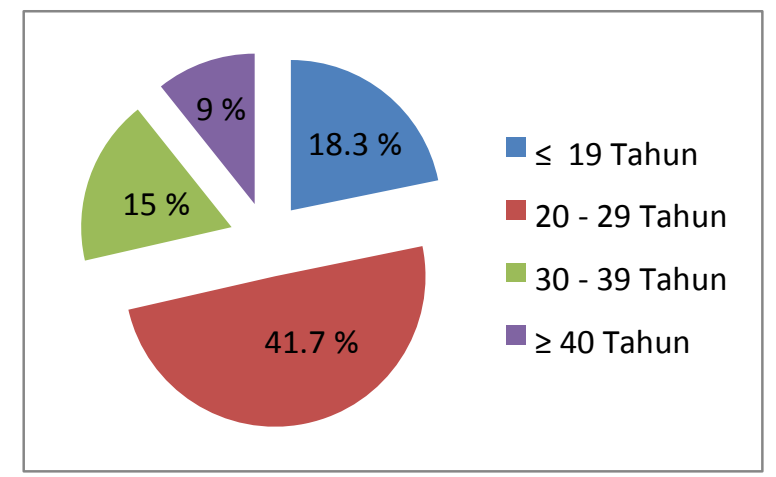

Gambar 2. Profil Responden Berdasarkan Usia

Data tersebut menunjukan bahwa yang yang menjadi pelanggan Salon Chiquita didominasi oleh konsumen yang berusia antara 20-29 tahun dengan jumlah sebanyak 41,7\%. Kemudian diikuti oleh konsumen yang berusia $\leq 19$ tahun dengan jumlah sebanyak $18,3 \%$, konsumen yang berusia antara 30-39 tahun dengan jumlah sebanyak 15\%, konsumen yang berusia antara $\geq 40$ tahun dengan jumlah sebanyak $9 \%$.

\section{Hasil Uji Regresi Linear Berganda}

Analisis regresi linear berganda adalah alat analisis statistik yang memberikan penjelasan tentang pola hubungan (model) dan pengaruh antara dua atau lebih variabel penelitian yang berbeda melalui beberapa hasil observasi di berbagai bidang kegiatan. Berkaitan dengan penelitian ini, alat analisis statistik parametrik regresi linear berganda digunakan untuk mengukur hubungan dan pengaruh dari variabel bebas (independen) yaitu variabel aktivitas, minat dan opini terhadap variabel terikat (dependen) yaitu keputusan konsumen menggunakan jasa Salon Chiquita di Kota Palu yang menjadi penelitian ini.

\section{Pengujian Hipotesis Pertama (Uji Serempak / Uji F)}

Pengujian hipotesis pertama yaitu untuk mengetahui apakah variabel aktivitas, minat dan opini secara serempak berpengaruh positif dan signifikan terhadap keputusan konsumen menggunakan jasa Salon Chiquita di Kota Palu. Untuk lebih jelasnya dapat dilihat pada Tabel 1 berikut ini: 
Tabel 1. Hasil Uji Regresi

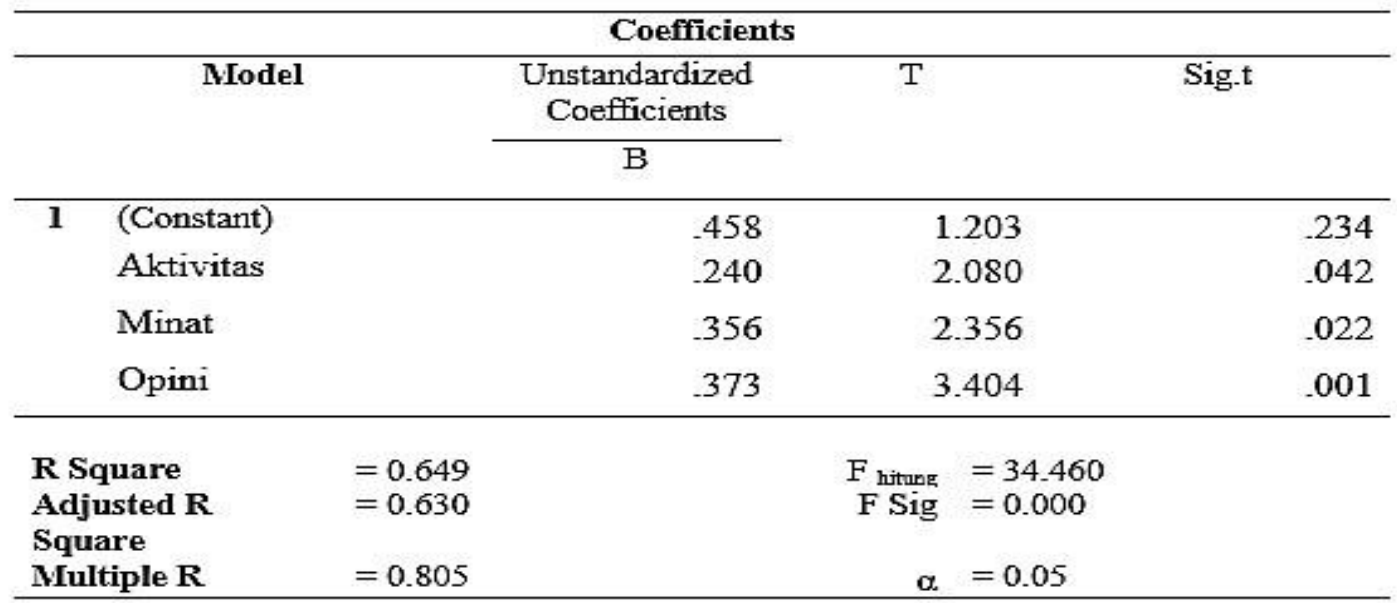

Sumber: Sumber: Data Primer, Diolah Kembali

Dari hasil uji regresi yang tertera pada Tabel 1 di atas, dapat diketahui bahwa persamaan regresinya adalah:

$$
\mathrm{Y}=0.458+0.240(\mathrm{X} 1)+0.356(\mathrm{X} 2)+0.373(\mathrm{X} 3)
$$

Berdasarkan persamaan regresi linear berganda di atas, dapat dijelaskan bahwa variabel aktivitas, minat dan opini. Berdasarkan perhitungan menunjukkan bahwa nilai $\mathrm{F}$ sig sebesar $0,000<\alpha$ $(0,05)$. Maka Ho ditolak dan Ha diterima, artinya variabel aktivitas, minat, dan opini secara serempak berpengaruh signifikan terhadap keputusan konsumen menggunakan Jasa Salon Chiquita di Kota Palu.

- Nilai konstanta sebesar 0.458 memberi pengertian bahwa jika variabel independen dianggap 0, maka keputusan konsumen menggunakan jasa Salon Chiquita di Kota Palu adalah 0.458

- $\quad$ Nilai koefisien Aktivitas bernilai positif sebesar 0.240. Artinya jika aktivitas naik satu-satuan dan variabel lain tetap maka keputusan konsumen menggunakan jasa Salon Chiquita di Kota Palu naik sebesar 0.240 .

- Nilai koefisien Minat bernilai positif sebesar 0.356. Artinya jika minat naik satu-satuan dan variabel lain tetap maka keputusan konsumen menggunakan jasa Salon Chiquita di Kota Palu naik sebesar 0.356 .

- Nilai koefisien Opini bernilai positif sebesar 0.373. Artinya jika opini naik satu-satuan dan variabel lain tetap maka keputusan konsumen menggunakan jasa Salon Chiquita di Kota Palu naik sebesar 0.373 .

Besar pengaruh koefisien determinasi R Square (R2) sebesar 0.649 artinya pengaruh variabel Aktivitas, Minat, dan Opini sebesar 64,9\% selebihnya 35,1\% dipengaruhi diluar model penelitian.

\section{Pengujian Hipotesis Ke Tiga (Uji Parsial/Uji t)}

Dari Tabel 1 bahwa besarnya probabilitas signifikansi dimensi minat (X3) adalah $0.022<$ taraf signifikansi yang diisyaratkan $\alpha 0,05$ dengan demikian bahwa secara statistik dimensi minat dalam penelitian ini memberikan pengaruh positif terhadap keputusan konsumen menggunakan jasa Salon Chiquita di Kota Palu.

\section{Pengujian Hipotesis Ke Empat (Uji Parsial/Uji t)}

Dari Tabel 1, bahwa besarnya probabilitas signifikansi dimensi opini (X3) adalah $0.001<$ taraf signifikansi yang diisyaratkan $\alpha 0,05$ dengan demikian bahwa secara statistik dimensi opini dalam penelitian ini memberikan pengaruh positif terhadap keputusan konsumen menggunakan jasa Salon Chiquita di Kota Palu. 


\section{Pembahasan Hasil Penelitian}

Pengaruh Variabel Aktivitas (X1)

Dalam penelitian ini, aktivitas diartikan bagaimana konsumen menghabiskan waktunya untuk berkunjung ke Salon Chiquita.

Hasil yang diperoleh pada penelitian ini diperoleh bahwa besarnya nilai t sig $0.042<\operatorname{taraf}$ signifikansi yang diisyaratkan $\alpha 0,05$ dengan demikian bahwa secara statistik aktivitas berpengaruh secara signifikan terhadap variabel dependen (keputusan konsumen) menggunakan Salon Chiquita di Kota Palu. Hal tersebut sesuai dengan penelitian yang dilakukan Ratri, Apriatni, dan Reni (2014), Penelitian ini dilatarbelakangi oleh adanya perpindahan dan penurunan minat pengunjung untuk menonton film di bioskop E-Plaza sejak hadirnya bioskop pesaing di Semarang yang dipengaruhi oleh beberapa faktor yakni gaya hidup dan persepsi harga. Penelitian ini ditunjukkan untuk menguji activity terhadap keputusan konsumen untuk menonton film di Bioskop E-Plaza Semarang.

Hasil wawancara yang dilakukan oleh peneliti, konsumen yang berkunjung ke Salon Chiquita tidak hanya sekedar untuk refreshing, tapi juga telah menjadi hobi. Dan dianggap cocok untuk menghabiskan waktu baik untuk diri sendiri maupun bersama keluarga ataupun teman yang memiliki hobi yang sama.

\section{Pengaruh Variabel Minat (X2)}

Dalam penelitian ini, minat diartikan sebagai segala sesuatu yang dianggap penting oleh konsumen yang ditawarkan oleh pihak Salon Chiquita. Hasil yang diperoleh pada penelitian ini diketahui bahwa besarnya nilai $\mathrm{t}$ sig $0.022<$ taraf signifikansi yang diisyaratkan $\alpha 0,05$ dengan demikian bahwa secara statistik minat berpengaruh secara signifikan terhadap variabel dependen (keputusan konsumen) mengunjungi Salon Chiquita di Kota Palu. Berkaitan dengan hal tersebut, Mandey (2009) juga melakukan penelitian yang bertujuan sama untuk mengetahui bagaimana pengaruh faktor gaya hidup (aktivitas, minat, pendapat) berpengaruh secara parsial dan simultan . Berdasarkan hasil pengamatan Salon Chiquita menyediakan berbagai macam merek (brand) produk kecantikan yang berkualitas sehingga membuat konsumen penasaran untuk datang dan menggunakan jasa. Perkembangan media sosial juga ikut menyumbangkan peran, dimana semakin maraknya pengguna media sosial sekarang mengunggah foto hasil dari perubahan yang diberikan oleh Salon Chiquita, sehingga semakin membuat penasaran pengguna media sosial lainnya.

\section{Pengaruh Variabel Opini (X3)}

Dalam penelitian ini, opini diartikan sebagai pandangan-pandangan konsumen terhadap dirinya sendiri maupun terhadap diri orang lain. Hasil yang diperoleh pada penelitian ini bahwa besarnya nilai $\mathrm{t}$ sig $0.001<$ taraf signifikansi yang diisyaratkan $\alpha 0,05$ dengan demikian bahwa secara statistik, opini berpengaruh secara signifikan terhadap variabel dependen (keputusan konsumen) menggunakan jasa Salon Chiquita di Kota Palu. Sehubungan dengan hal itu penelitian yang dilakukan Mandey (2009) juga menunjukan bahwa variabel opini berpengaruh signifikan Berdasarkan hasil pengamatan yang dilakukan peneliti, konsumen di Kota Palu sangat tertarik dengan tempat khususnya Salon Chiquita dengan layanan yang baik serta dikerjakan oleh tenaga kecantikan yang profesional. Hal tersebut yang dimanfaatkan oleh Salon Chiquita untuk menarik konsumen khususnya para wanita di Kota Palu.

Dari ketiga Variabel yang telah diuraikan terlihat bahwa variabel yang paling dominan adalah variabel opini, dimana variabel opini mempunyai besar pengaruh secara parsial sebesar 0.373, kemudian diikuti variabel minat dengan besar pengaruh secara parsial 0.356, dan yang terakhir adalah variabel aktivitas dengan nilai pengaruh secara parsial sebesar 0.240, hal ini menunjukan bahwa opini atau pendapat konsumen mengenai Salon Chiquita bersifat positif terlihat dari banyaknya konsumen yang telah menjadi pelanggan tetap salon ini. Tidak sedikit pelanggan yang sudah pernah mencoba 
datang lagi dan lagi, bahkan setiap harinya semakin banyak wajah baru yang berkunjung ke Salon Chiquita, hal ini tentunya bukan hanya karena promosi melalui radio atau brosur yang disebar melainkan karena adanya gethok tular (word of mouth) dari pelanggan yang puas akan kualitas jasa Salon Chiquita.

Opini merupakan hal penting yang memang harus dipertimbangkan, pihak Salon Chiquita tentunya berusaha keras untuk menciptakan opini yang positif terhadap salon ini. Terlihat jelas bagaimana perubahan yang terjadi pada Salon Chiquita di mana dulunya salon ini hanya salon kecil yang berdinding papan sekarang sudah memiliki bangunan ruko sendiri dan sudah mempunyai anak cabang yaitu Salon Chiquita yang beralamat di jalan Poebongo, Ruko Catur No. 13. Bukan hanya karena kualitas jasanya yang bagus, tetapi karena pelayanan yang baik dan harga yang terjangkau, serta pihak Salon Chiquita tidak segan-segan untuk mengganti rugi atau memberikan jaminan terhadap pelanggan yang tidak puas akan hasil yang didapat. Dengan adanya opini yang positif maka prospek usaha Salon Chiquita untuk kedepannya akan semakin baik.

\section{KESIMPULAN DAN SARAN}

\section{Kesimpulan}

Dari hasil penelitian yang dilakukan di Salon Chiquita Kota Palu adapun kesimpulan dalam penelitian ini, yaitu :

1. Aktivitas, Minat dan Opini secara simultan memberikan pengaruh positif terhadap keputusan konsumen menggunakan Jasa Salon Chiquita di Kota Palu.

2. Aktivitas (X1) memberikan pengaruh positif terhadap keputusan konsumen menggunakan Jasa Salon Chiquita di Kota Palu.

3. Minat (X2) memberikan pengaruh positif terhadap keputusan konsumen menggunakan Jasa Salon Chiquita di Kota Palu.

4. Opini (X3) memberikan pengaruh positif terhadap keputusan konsumen menggunakan Jasa Salon Chiquita di Kota Palu.

\section{Saran}

Berdasarkan pada penelitian yang telah dilakukan dan hasil kesimpulan yang diperoleh, maka saran yang diajukan dalam penelitian ini adalah sebagai berikut:

1. Kepada pihak Salon Chiquita , harus terus mengontrol dan mengevaluasi variabel-variabel yang terbukti memberikan pengaruh yang signifikan terhadap keputusan konsumen dalam melakukan pembelian jasa mereka, kemudian melakukan inovasi-inovasi baru agar lebih menarik penggunjung misalnya membuat klub kecantikan yang agendanya tidak hanya membahas perawatan dari luar tetapi juga perawatan dari dalam tubuh. Selanjutnya bagaimana jika Salon Chiquita juga menyediakan makanan-makan sehat untuk para pelanggan yang menunjang kecantikan dari dalam tubuh, serta pihak Salon Chiquita juga harus tetap menjaga dan meningkatkan kualitas produk yang digunakan dalam mengaplikasikan jasanya. Pihak Salon Chiquita harus mempertahankan keunggulan dari salon ini, memberikan pelayanan spesial buat pelanggan setiap Salon Chiquita, agar semakin banyak peminat untuk pergi ke Salon Chiquita serta untuk peningkatan baik dari segi produktivitas dan efektivitas perusahaan maupun dari segi keuntungan perusahaan.

2. Untuk penelitian selanjutnya, diharapkan untuk mencari, menambahkan, atau bahkan mengkombinasikan variabel-variabel pembentuk keputusan menggunakan jasa Salon Chiquita, agar hasil penelitiannya memberikan kontribusi yang bermakna pada pihak-pihak yang berkepentingan. 
Lestari, W.

3. Kepada pihak-pihak yang berkepentingan diharapkan dapat memberikan saran dan tanggapan untuk penulis dalam penelitian ini.

\section{REFERENSI}

Kotler, P. \& Kevin L.K. 2009. Manajemen Pemasaran, Edisi Ke Tiga Belas Jilid I \& II, Terjemahan Bob Sabran, PT. Erlangga, Jakarta.

Mandey, Silvya L, 2009. Pengaruh Faktor Gaya Hidup Terhadap Keputusan Pembelian Konsumen. Jurnal Ekonomi Bisnis Analisis, Vol 6, No. 1, 92-100, ISSN 08528144,http://ejournal.undip.ac.id, Diakses 29 September 2015.

Setiadi, N. J, 2013. Perilaku Konsumen Edisi Revis i: Perspektif kontemporer pada motif, tujuan, dan keinginan konsumen, Kencana, Jakarta.

Sunyoto, D, 2014. Dasar-Dasar Manajemen Pemasaran (Konsep, Strategi, dan Kasus), PT. Buku Seru, Jakarta

Sugiyono. (2010). Metode Penelitian Bisnis. Bandung: Alfabeta. 